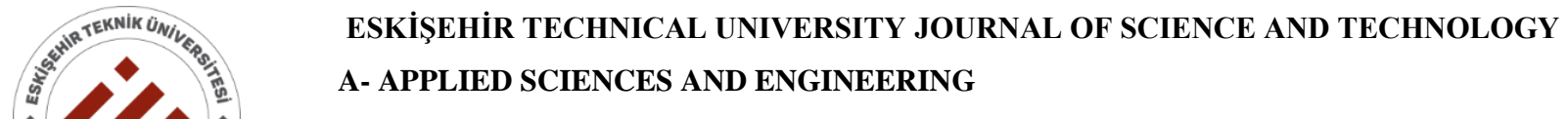

ESTIŞEHIR TECHNICAL UNIVERSITY JOURNAL OF SCIENCE AND TECHNOLOGY

A- APPLIED SCIENCES AND ENGINEERING

$2020,21(3)$, pp. 407-420, DOI: 10.18038 /estubtda. 663717

RESEARCH ARTICLE

\title{
A CASE STUDY ON PILE DESIGN OF WIND TURBINE FOUNDATION (KAHRAMANMARAS-TURKEY)
}

\author{
Alirıza İlker AKGÖNEN 1, * (D), Ahmet ÖZBEK ${ }^{2}$ \\ ${ }^{1}$ Department of Civil Engineering, Kahramanmaraş Sutcu Imam University, Kahramanmaraş, Turkey \\ ${ }^{2}$ Department of Geological Engineering, Kahramanmaraş Sutcu Imam University, Kahramanmaraş, Turkey
}

\begin{abstract}
In recent years, in parallel with the developing technology not only in the world but also in Turkey, Wind Power Plants (WPP), which are among the renewable energies, are widely constructed. To build the wind turbines safely, the units of the turbine site area should not exhibit weakness, have sufficient bearing capacity, and do not have the risk of settlement and liquefaction. On the other hand, a structural analysis of a bored pile under mat foundation takes an important place in a foundation design of wind turbines. However, there is no design guideline for the wind turbine foundation design for structural engineers.

Kale Energy constructed wind power plants within the scope of the Dilek WPP project located in Alanlı Village, Andirın District, Kahramanmaraş Province. According to the geological and geotechnical studies carried out in the turbine areas, it was determined that the units of the T-12 turbine were weak, and the bearing capacity was determined as insufficient. For this reason, it was planned to carry out the necessary improvement works with the application of piles to ensure adequate bearing capacity of the foundation. This study covers the geotechnical and structural analysis of a bored pile under the mat foundation. As a result of the analyzes, thirty-seven piles were placed under the mat foundation. The length and diameter of the bored pile are determined as 15 and 0.8 meters, respectively. The pile spacing from center to center was used as 3 meters.
\end{abstract}

Keywords: Geotechnical, Wind Power Plant, Bearing Capacity, Bored Pile, Rock Mass Properties

\section{INTRODUCTION}

Wind is a free, clean, renewable, and non-polluting energy source. Due to these advantages, wind energy is one of the most effective and fastest-growing energy sources among alternative power supplies. The leading countries on the usage of wind energy can be listed as China, the United States, and Germany. Wind power capacity in Turkey is gradually increasing mainly in the Aegean and Marmara regions. However, in recent years, the South and South-East region of Turkey has drawn investor's attention with its high potential of wind power. Annual and cumulative installations for Wind Power Plants (WPP) in Turkey is presented in Figure 1 [1].

Kale Energy company has established 27,5 MW named Dilek Wind Power Plant (WPP) in Andırın, Kahramanmaraş, Turkey. Eleven Nordex (N117/2400) with 2,4 MW capacity wind turbines have been used. Installed WPP's have a hub height of 90 meters and a rotor diameter of 116,8 meters. Dilek WPP is capable of meeting the electricity needs of approximately 13.850 people [2]. WPP's are generally high structures that are subjected to large horizontal forces. To eliminate the risk of overturning of the structure and to reduce the width of the foundation, the use of a piled-raft foundation is generally inevitable. In this study, the pile design of the T-12 wind turbine was explained. There is no guideline for wind turbine foundation design for structural engineers. Therefore, experience gained with the use of a mat-pile foundation for the construction of a 2,4 MW wind turbine in Kahramanmaraş was presented with all details.

*Corresponding Author: ilkerakgonen@ksu.edu.tr

Received: 23.12.2019 Published: 30.09.2020 
Akgönen ve Özbek / Eskişehir Technical Univ. J. of Sci. and Tech. A-Appl. Sci. and Eng. 21 (3) - 2020

Annual Installations for Wind Power Plants in Turkey (MW)

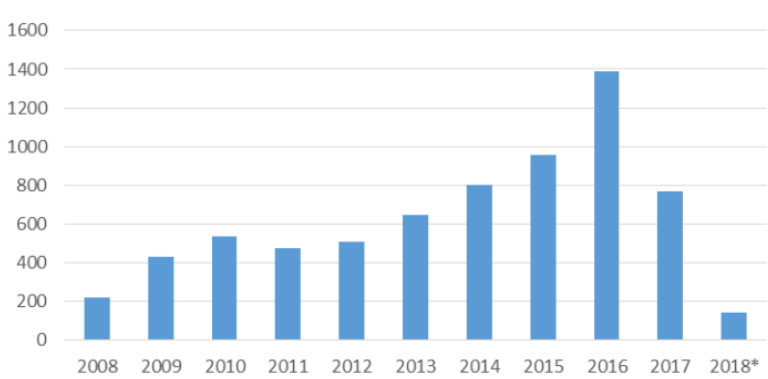

Cumulative Installations for WPP in Turkey (MW)

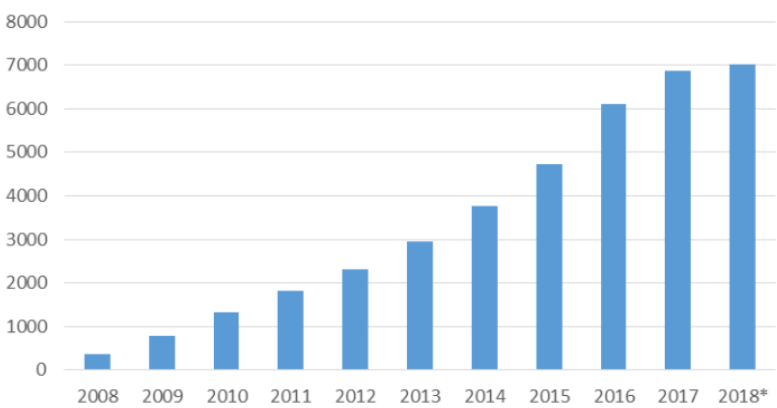

Figure 1. Annual and cumulative installations for wind power plants (WPP) in Turkey [2]

The study of the foundation design of wind turbines has attracted the attention of many researchers. Dilley et al. [3] conducted a case study on the foundation design of wind turbines that provides electrical power to 51 villages in southwest Alaska. Because of the turbine base area consisting of sandy and silty soils, they proposed an innovative foundation design, including the use of helical piers to support a steel and concrete foundation. Malhotra [4] examined the selection, design, and construction of offshore wind turbine foundations. In his work, six basic types of offshore wind turbine support structures and foundations were described, along with their advantages and drawbacks. General considerations in the selection, design, analyses, and construction of these structures were presented. Buren and Muskulus [5] identified and explained performing a dynamic analysis of an offshore wind turbine with an aero-elastic solver relies on the inclusion of a model to represent the behavior of the piled foundations. They stated that the P-Y method was developed for offshore oil-gas applications and the offshore wind power industry but there were a few deficiencies related to this method that could affect the accuracy of wind turbine simulations. These shortcomings were identified and explained in their work. Catana et al. [6] carried out a study on soil-structure interaction modeling for wind turbines. The authors take on the task of modeling the soil-structure interaction for the mat and piles considering three separate models. Yoon et al. [7] conducted a reliability analysis of offshore wind mono-pile foundation, using the response surface method. Ming-Jie et al. [8] worked on the mono-pile foundation of the offshore wind turbine which was simulated by using the ANSYS finite element software. They conducted a quasi-static analysis of the foundation of the offshore wind turbine considering the interactions of environmental loads, such as wind, wave, current, etc., and optimized the size of the pile based on the zero-order method. Shrestha [9] studied the economic advantages of using the raft foundations, pile group foundations and piled-raft foundations based on the geotechnical design results and parametric studies used both analytical and numerical simulations using GROUP and PLAXIS 3D software. Sandal and Zania [10] used numerical methods for the structural design optimization to design piles for offshore wind turbine jacket foundations. The pile mass was minimized with constraints on the axial and lateral capacity.

The DİLEK WPP is located on the eastern border of the Andırın town of the Kahramanmaras province (12 km to Andırın town and $58 \mathrm{~km}$ to Kahramanmaraş city center; Figure 2). Each turbine has a body part on the foundation, a Hub, and 3 blades. The amount of foundation concrete of the individual turbine was $680 \mathrm{~m}^{3}$ and covers an area of 331-meter square in the octagonal form (Figure 3, Figure 5).

The Middle-Upper Miocene Karataş formation is exposed in and around the turbine T-12. The unit is generally composed of sandy marl, conglomerate, shale, sandstone, sandstone-shale alternation, clayey limestone, marl, and conglomerate. These units contain three main sequences, whose base contain sandstone-shale-marl alternation. In the upper part, the unit transitionally passes into the carbonate cemented sandstone, conglomerate, carbonated claystone, and marl alternation, then the unit contains an alternation of the gray, erosive based, thickly bedded conglomerate (product of grain or debris flow), thickly bedded-locally massive sandstone and thickly bedded-graded-laminated carbonate 
cemented sandstone, shale and olistostrome pebbly shale including Eocene-Miocene limestone olistostrome.

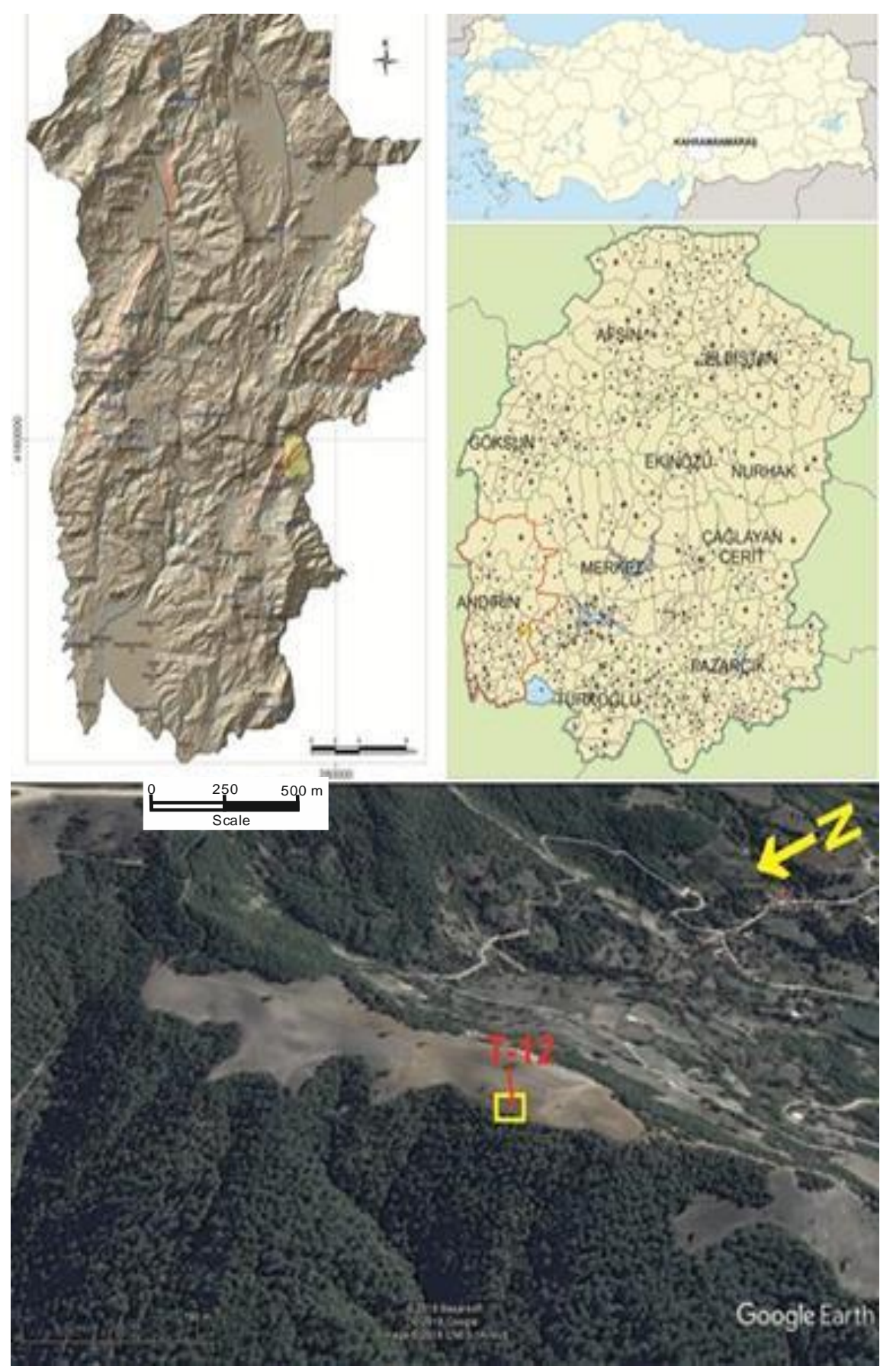

Figure 2. Satellite image showing the location of the turbine T-12 in the study area. 

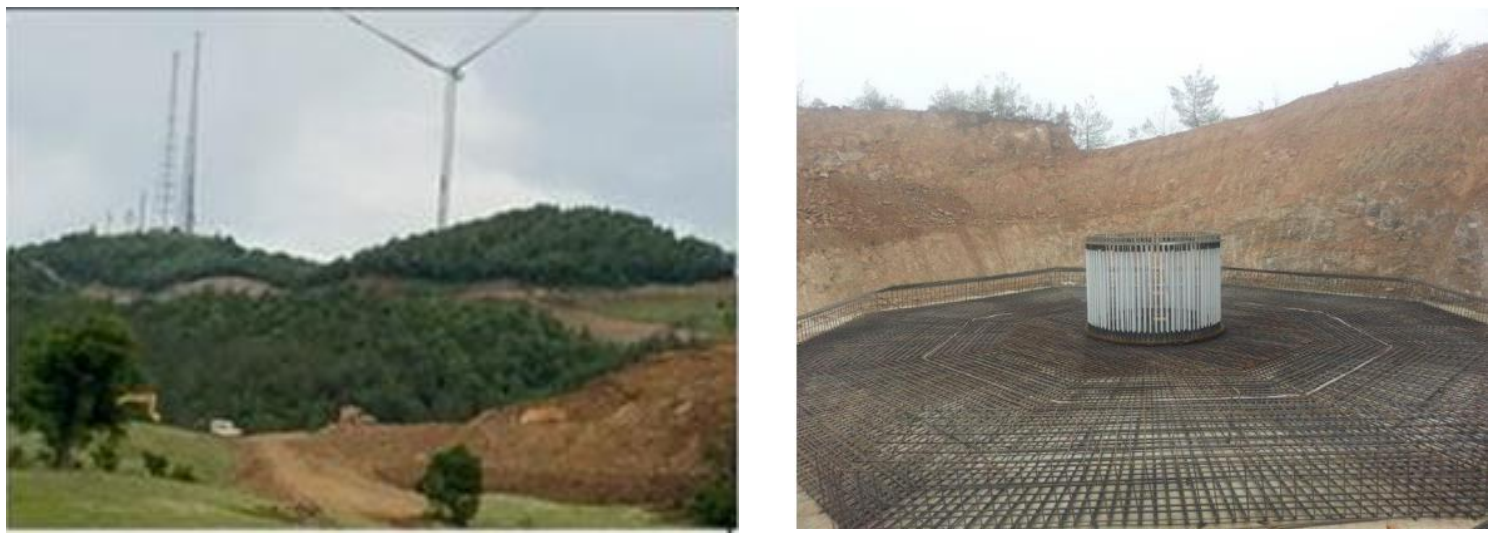

Figure 3. General view and foundation view of the wind turbine [1].

\section{GEOTECHNICAL PARAMETERS}

The sandstone and claystone in the T-12 turbine basement area are weathered by tectonism and atmospheric conditions, and the results present a disintegrated structure (Figure 4). The proportion of claystone is much higher than the sandstone. $30 \mathrm{~m}$ deep borehole was drilled in the study area.

In general, weathered mostly sandstone and claystone alternations, mostly claystone and sandstone alternations, and sandstone beds were observed. The claystone was significantly disintegrated on the surface and relatively less disintegrated towards the subsurface.

According to [11] and [12] standards, dry-saturated unit weight, specific gravity, apparent porosity, void ratio, and uniaxial compressive strength values of the samples have been determined (Table 1).

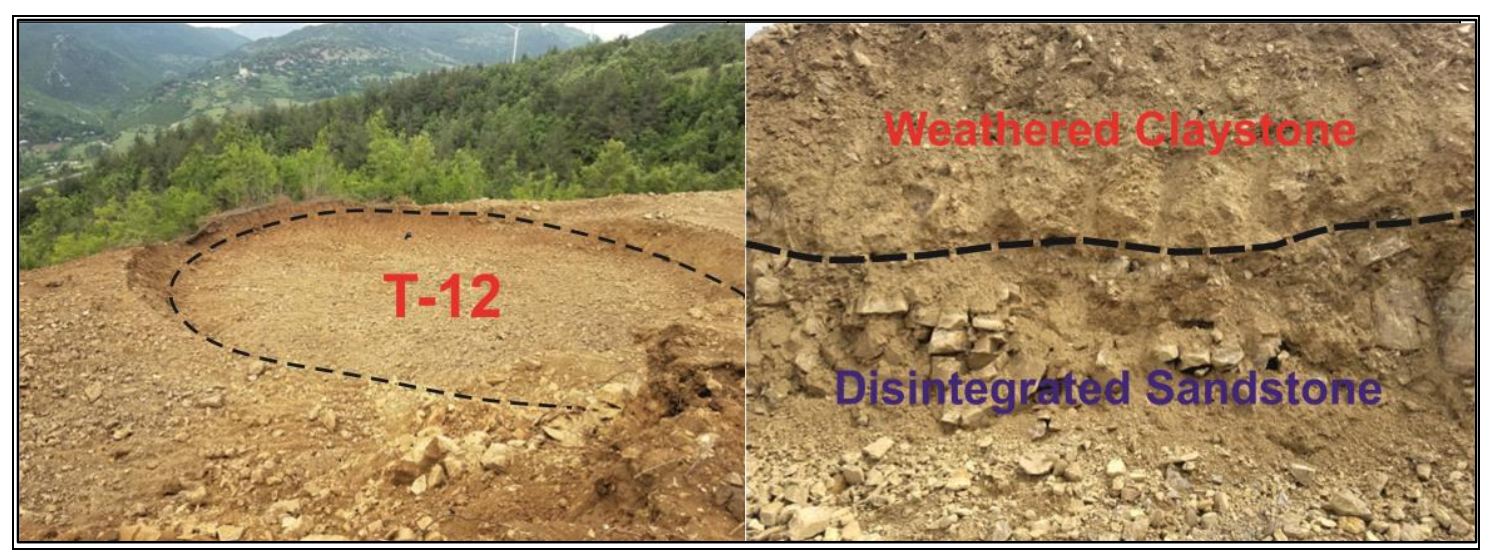

Figure 4. The weathered claystone and disintegrated sandstone units in the T-12 wind turbine area

Table 1. Physical and mechanical properties of the samples from the study area.

\begin{tabular}{|c|c|c|c|c|c|c|c|}
\hline \multirow{2}{*}{ 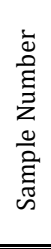 } & \multirow{2}{*}{ 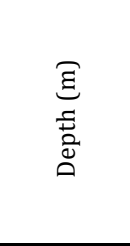 } & 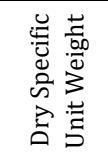 & 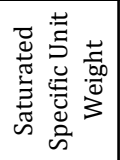 & 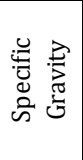 & 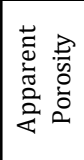 & 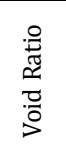 & $\begin{array}{c}\text { Uniaxial } \\
\text { Compressive } \\
\text { Strength Test }\end{array}$ \\
\hline & & $\begin{array}{c}\gamma_{\mathrm{n}} \\
\left(\mathrm{kN} / \mathrm{m}^{3}\right)\end{array}$ & $\begin{array}{c}\gamma_{\mathrm{k}} \\
\left(\mathrm{kN} / \mathrm{m}^{3}\right) \\
\end{array}$ & Gs & n (\%) & e & $\sigma_{\mathrm{c}}(\mathrm{MPa})$ \\
\hline 1 & $4.00-7.50$ & 22.10 & 22.88 & 2.65 & 8.67 & 0.09 & 33.84 \\
\hline 2 & $8.00-10.00$ & 23.19 & 23.76 & 2.69 & 7.03 & 0.08 & 32,00 \\
\hline
\end{tabular}




\subsection{Rock Mass Properties}

A "The Hoek Brown Failure Criteria", which was proposed by Hoek and Brown [13-14], has been used for the estimation of the deformation and strength characteristics of studied rock masses, composed of heterogeneous sandstone-claystone alternation in the study area. "The Hoek Brown Failure Criteria" for jointed rock masses is defined in equation (1).

$$
\sigma_{1}=\sigma_{3}+\sigma_{c i} *\left(m_{b} * \frac{\sigma_{3}}{\sigma_{c i}}+s\right)^{a}
$$

$\sigma_{1}$ and $\sigma_{3}$ are the maximum and minimum effective stresses at the time of failure, respectively. $m_{b}$ is the Hoek Brown's constant for rock masses, $s$ and $a$ are constants based on the rock mass characteristics and $\sigma_{c i}$ is the uniaxial compressive strength of a intact rock piece.

This failure criterion is based on the three basic parameters for determining the strength and deformation characteristics of rock masses [15-19]. These are uniaxial compressive strength of intact rock $\left(\sigma_{c i}\right)$, the Hoek-Brown constant value $m i$, and Geological strength index (GSI). The uniaxial compressive strength $\left(\sigma_{c i}\right)$ was obtained from the sandstone cores in the study area where heterogeneous sandstone-claystone alternations were observed (Table 1). The $m i$ value to be used for all rock groups was determined as 13 for sandstone-claystone alternation using the table proposed by Marinos and Hoek [17].

Marinos and Hoek [17] asserted that both the sandstone and the claystone could not be directly used in the determination of the $\sigma_{c i}$ and $m i$ parameters of heterogeneous rocks by laboratory or field tests. Instead, they emphasized that an average value representing both units should be used. These investigators suggested that the strength $\left(\sigma_{c i}\right)$ and $m i$ parameters of the heterogeneous sandstoneclaystone intercalations containing hundreds of layers of stratification, such as those in the study area, should be lower than the values determined by the intact sandstone layers. It was stated that an average value should be taken by applying some reduction according to the rock mass class determined based on the characteristics of claystone sandstone ratio, faulting, and folding. The $\sigma_{c i}$ and $m i$ values of the heterogeneous sandstone-claystone alternations of the study area were obtained from the table by decreasing the proportions based on fields observation presented by Marinos and Hoek [17]. Therefore, the $\sigma_{c i}$ was determined as $19.20 \mathrm{MPa}, m i$ value was 7.80 and both values were used in the calculations.

Table 2 was proposed by Marinos and Hoek [17] to determine the GSI value for the flysch heterogeneous rock masses. According to this table, it was determined that the turbine area T-12 was in composition and structure in class $\mathrm{E}$. The surface conditions of the discontinuity were defined as highly weathered having a smooth, hard or angular fragment. Based on these two parameters (Composition structure and surface condition of discontinuities) and field observations, the GSI value was chosen as 28 from Table 2 . The analyses to determine the strength and deformation characteristics of units in the study area were performed using the RocData 5.0 [20]. As the foundation excavation was carried out by hand or construction machinery, the disturbance factor (D) was taken as a 0,7 . As a result of the analysis, cohesion (c) was obtained as $0,35 \mathrm{MPa}$, the internal friction angle $(\phi)$ was $12.29^{\circ}$ and the modulus of elasticity (E) was $128,12 \mathrm{MPa}$ (Figure 4). 
Table 2. GSI estimates for heterogeneous rock masses such as flysch [16].

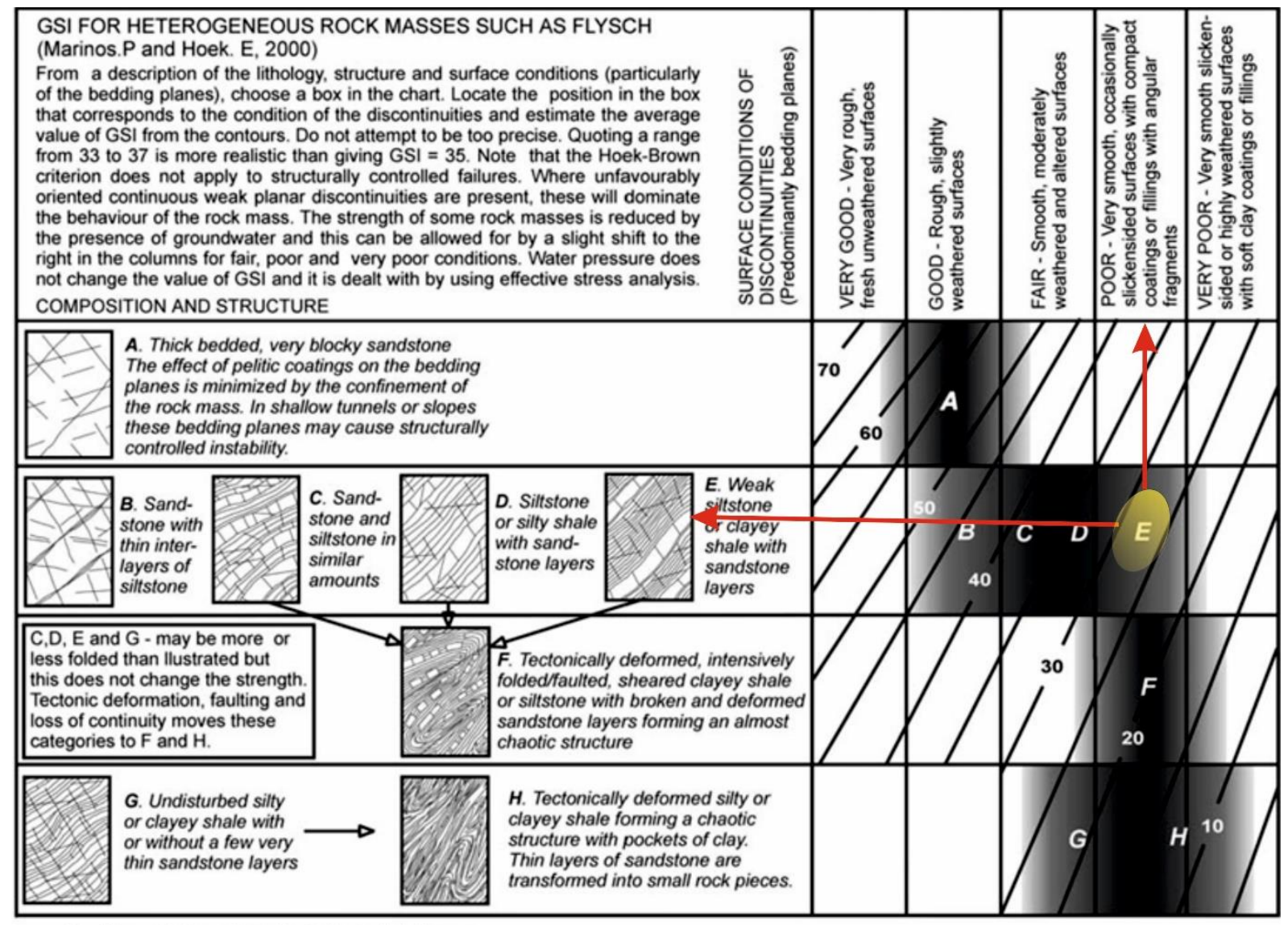

: Means deformation after tectonic disturbance
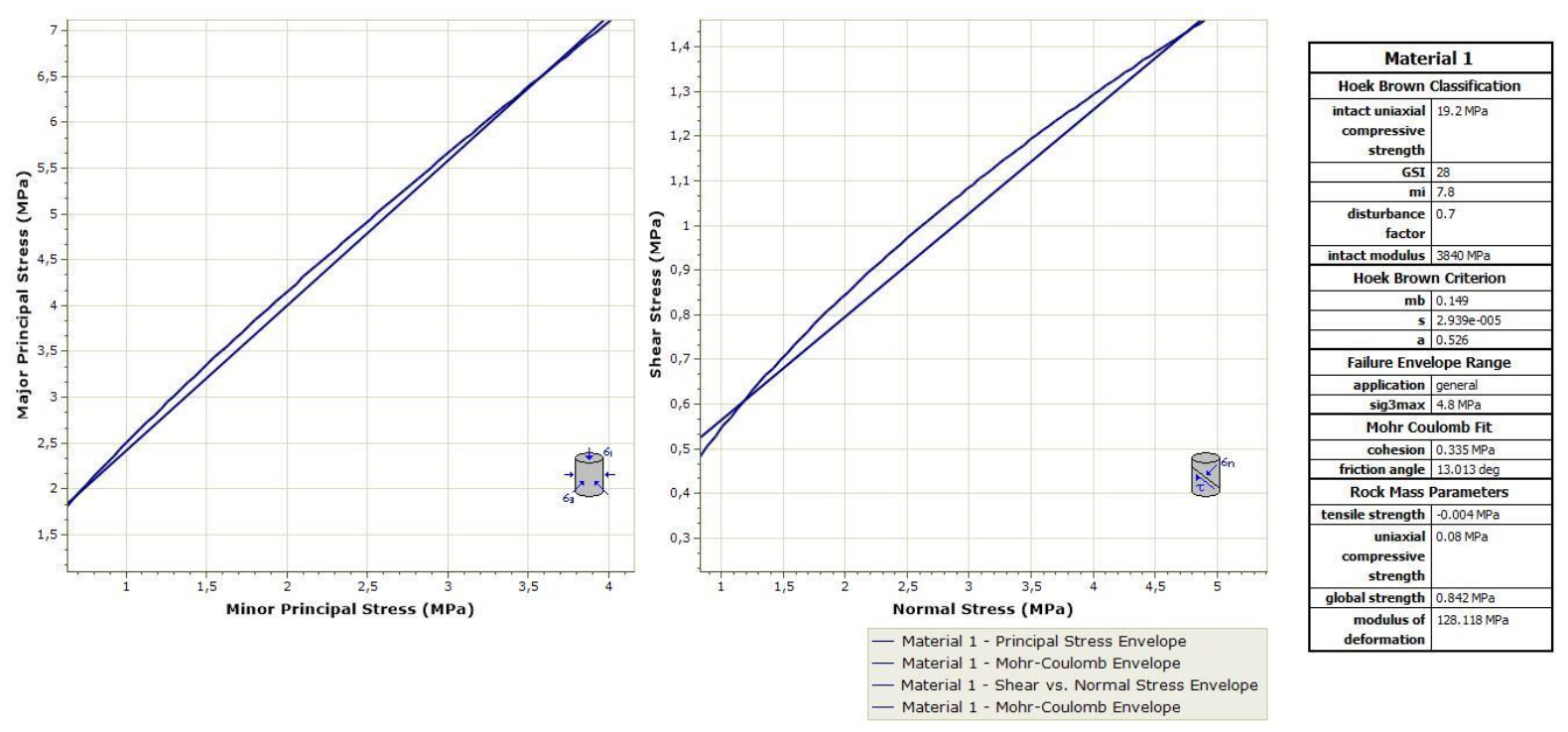

Figure 5. Rock mass parameters according to the Hoek Brown failure criterion for T-12. 


\subsection{Ultimate Bearing Capacity}

Sandstone-claystone units in the study area presents a fractured and weathered structure near the surface. Therefore, in the highly jointed (cracked) rocks, the ultimate bearing capacity $\left(q_{u l t}\right)$ was calculated according to the Hoek-Brown Failure criterion, using the following equation [21].

$$
q_{u l t}=C_{f 1} * s^{1 / 2} * \sigma_{c} *\left[1+\left(m b * s^{-\frac{1}{2}}+1\right)^{\frac{1}{2}}\right]
$$

Where, $C_{f 1}$ is the dimensionless correction factor due to its basement shape. $m_{b}$ and $\mathrm{s}$ are constant values depend on degree of joint of fractured rock $(\mathrm{mb})$ and rock type $(s) . \sigma_{c}$ is the uniaxial compressive strength of rock. The ultimate bearing capacity (qult) of the units in the turbine area T-12 was determined by considering the circular foundation. In the calculations, revised uniaxial compressive strength values $\left(\sigma_{c}\right)$ determined by the laboratory tests, $m b$ and $s$ parameters determined using the RocData program, and $C_{f l}$ values determined from the table proposed by Sowers [22]; from Wyllie [21], were used. Ultimate bearing capacity was calculated as $8,13 \mathrm{kgf} / \mathrm{cm}^{2}$ considering the circular basis for the turbine area T-12.

\section{PILE DESIGN OF T-12 WIND TURBINE}

The basic parameters for the design of the pile (Table 3) to be applied in the study area were determined using the parameters given in Table 1 and Figure 5. The required information about the superstructure presented in Table 3 was obtained from the contractor firm and used in the design.

Table 3. Ground, material and superstructure parameters used in the bored pile design

\begin{tabular}{ll}
\hline Soil parameters & \\
\hline Ultimate bearing capacity (q ultimate) & $8,13 \mathrm{kgf} / \mathrm{cm}^{2}$ \\
Cohesion $(\mathrm{c})$ & $0,35 \mathrm{MPa}$ \\
Angle of internal friction $(\Phi)$ & $12,29^{\circ}$ \\
Friction angle between pile and soil $(\delta)$ & $8,23^{\circ}$ \\
Horizontal and vertical modulus of sub-grade reaction $(\mathrm{K})$ & $3.252,0 \mathrm{ton} / \mathrm{m}^{2}$ \\
Unit volume weight of soil $\left(\mathrm{\gamma}_{\mathrm{n}}\right)$ & $22 \mathrm{kN} / \mathrm{m}^{3}$ \\
Safety factor & 2 \\
\hline Material properties & Value \\
\hline Quality of concrete & $\mathrm{C} 35 / 45$ \\
Quality of steel & $\mathrm{S} 420$ \\
Allowable steel strength $\left(\mathrm{f}_{\mathrm{yd}}\right)$ & $420 / 1,15=365,22 \mathrm{MPa}$ \\
$\mathrm{f}_{\mathrm{ywd}}$ & $420 / 1,15=365,22 \mathrm{MPa}$ \\
$\mathrm{f}_{\mathrm{ctd}}$ & $1,4 \mathrm{MPa}$ \\
\hline Superstructure data used for the pile design & Value \\
\hline Weight of foundation $\left(\mathrm{W}_{\text {foundation }}\right)$ & $1.667,0$ ton \\
Soil weight above foundation $\left(\mathrm{W}_{\text {soil }}\right)$ & 864,0 ton \\
Weight of superstructure $\left(\mathrm{Wind}_{\text {turbine }}\right)$ & 342,0 ton \\
Axial force determined by most unfavorable load case & $2.873,0$ ton \\
Shear force $\mathrm{V}_{\mathrm{x}}=\mathrm{V}_{\mathrm{y}}$ & 89,8 ton \\
Overturning moment $\mathrm{M}_{\mathrm{xx}}=\mathrm{M}_{\mathrm{yy}}$ & $7.788,30$ ton-meter \\
\hline
\end{tabular}

\subsection{Estimating Acting Forces to Pile}

Piles are effectively subjected to two different forces: axial and shear load. Overturning moment causes axial tension and compression forces on the piles. The axial force increases toward the edges and decreases toward the center. The horizontal forces such as wind, earthquake, and torsional moment acting on the superstructure cause a shear force between the mat foundation and the top of the bored pile. The foundation size was determined as $20 \mathrm{~m}$ x $20 \mathrm{~m}$ that has an octagonal shape. Thirty- 
seven piles were placed under the mat foundation. (Figure $6 a, 6 b$ ). The pile axial forces arising from the overturning moment of the superstructure were calculated with the assumption of an infinite rigid mat foundation (Figure 7a,7b). The calculated forces are presented in Table 4.

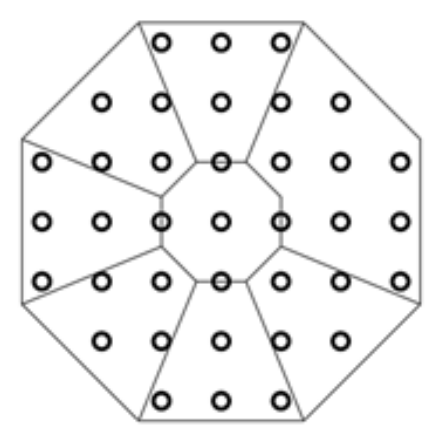

a)

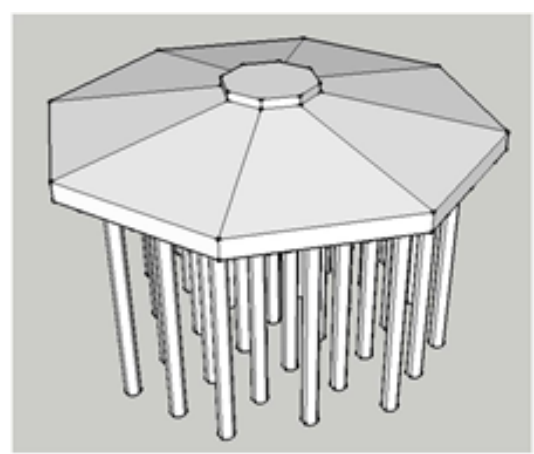

b)

Figure 6. a) Plan view of the piled-raft foundation with 37 piles, b) 3D view of the piled-raft foundation

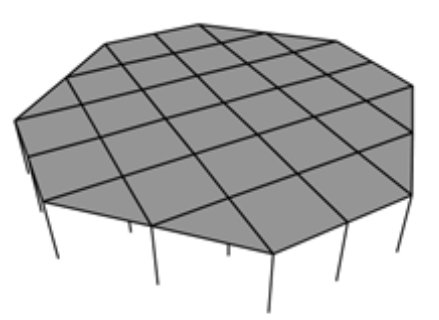

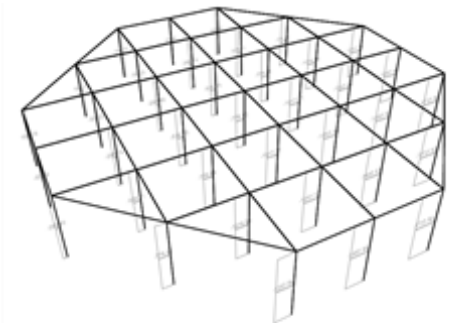

b)

Figure 7. a) Numerical model of the slab-pile foundation, b) Axial forces acting on the piles (ton)

Table 4. Axial forces acting on the pile

\begin{tabular}{cccc}
\hline $\begin{array}{c}\text { Pile } \\
\text { Number }\end{array}$ & $\mathbf{P}(\mathbf{k N})$ & $\begin{array}{c}\text { Pile } \\
\text { Number }\end{array}$ & $\mathbf{P}(\mathbf{k N})$ \\
\hline 1 & $-295,597$ & 20 & $-536,246$ \\
2 & $-55,244$ & 21 & $-295,741$ \\
3 & 185,145 & 22 & $-55,244$ \\
4 & $-776,405$ & 23 & $-1.737,8$ \\
5 & $-536,105$ & 24 & $-1.497,67$ \\
6 & $-295,741$ & 25 & $-1.257,49$ \\
7 & $-55,328$ & 26 & $-1.017,17$ \\
8 & 185,108 & 27 & $-776,644$ \\
9 & $-1257,06$ & 28 & $-536,105$ \\
10 & $-1.016,89$ & 29 & $-295,597$ \\
11 & $-776,644$ & 30 & $-1.737,92$ \\
12 & $-536,246$ & 31 & $-1.497,67$ \\
13 & $-295,796$ & 32 & $-1.257,32$ \\
14 & $-55,328$ & 33 & $-1.016,89$ \\
15 & 185,145 & 34 & $-776,405$ \\
16 & $-1.497,46$ & 35 & $-1.737,8$ \\
17 & $-1.257,32$ & 36 & $-1.497,46$ \\
18 & $-1.017,17$ & 37 & $-1.257,06$ \\
19 & $-776,819$ & & \\
& Total & & $-28.730,0$ \\
\hline
\end{tabular}


The most critical axial force was determined as $1,738,0 \mathrm{kN}$ and the critical shear force acting on a pile was determined as $898 / 37=24,27 \mathrm{kN}$. Shear force is not shared equally among piles. For this reason, a safety factor $(1,5)$ was used to determine the design shear force acting on the most critical pile. According to the symmetry of the superstructure body about principle axes, shear force that occurs because of the torsional moment was ignored.

\subsection{Estimating Axial Load Capacity of Pile Due to Soil Conditions}

There are many factors affecting pile ultimate capacity such as the soil properties, pile installation method, and geometrical properties of the pile. The piles resist the forces through the tip resistance and skin friction along its length. Friction piles carry a significant part of their loads by the friction and adhesion between their surface and the surrounding soils. Besides, the end-bearing piles rely on the bearing capacity of the soil underlying their bases (Figure 8). Usually, the end-bearing piles are used to transfer most of their loads to a stronger layer of rock or very dense soil that exists at a reasonable depth [23].

The ultimate bearing capacity of a pile is calculated according to equation 3 .

$$
Q_{u}=Q_{t i p}+Q_{s}
$$

Where, $Q_{t i p}$ is the pile tip resistance, $Q_{s}$ is the skin friction.

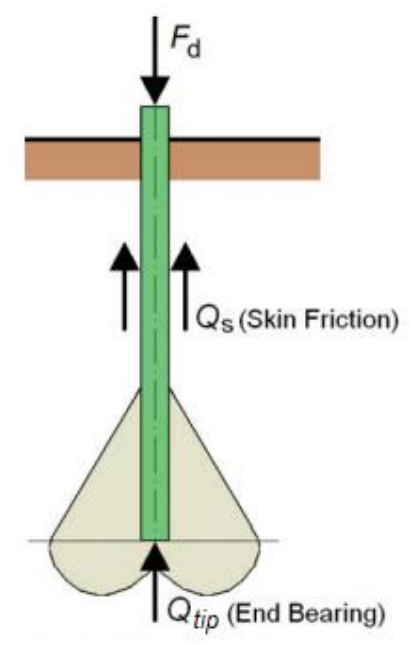

Figure 8. Pile's side friction (skin friction) and end bearing [22].

$$
Q_{\text {tip }}=1.3 * c * N_{c}+\gamma_{n} * D_{f} * N_{q}+0.3 * D * \gamma_{n} * N_{\gamma}
$$

The depth of the pile tip $\left(D_{f}\right)$ was chosen as 15 meters and the diameter of each pile was chosen as 0,8 meter. The cohesion $(c)$ was taken as $350 \mathrm{kN} / \mathrm{m}^{2}$ and the unit weight of soil $\left(\gamma_{n}\right)$ was taken as 22 $\mathrm{kN} / \mathrm{m}^{3}$ from table $4 . N_{c}, N_{q}, N_{\gamma}$ are Terzaghi's bearing capacity factors depending on soil friction angle, $(\varphi: 12)$. Pile side friction capacity $\left(\mathrm{Q}_{\text {fric }}\right)$ can be calculated from the equation 5 .

$$
Q_{\text {fric }}=\pi * D * K * \tan \delta *\left(\frac{D_{f}^{2}}{2}\right)
$$

Where, $\mathrm{K}$ is the active pressure coefficient, $\mathrm{D}$ is the diameter of the pile, $\mathrm{D}_{\mathrm{f}}$ is the length of the pile, $\delta$ is the friction angle between soil and pile surface which was determined as $\delta=0,75^{*} \varphi$

The capacity of the pile group equals the summation of the individual capacities of piles. However, in some cases, the load capacity of the pile group is less than the summation of the individual capacities 
of the pile. When the piles are placed very close to each other, the pressure bulb of individual pile overlaps and this causes the decrease of bearing capacity of the pile group due to the increase of soil stress at the overlap zone [24]. The distance between the piles from center to center was chosen as 3 meters which is greater than $3 \times \mathrm{D}=3 \times 0,8=2,4$ meters. Thus, the pile friction capacity was not decreased due to the overlap of the pressure bulb. The safety factor to determine the allowable bearing capacity of the pile was selected as 2 . The final allowable bearing capacity was calculated by subtraction of the pile own weight from gross allowable bearing capacity. The tip bearing capacity, side friction capacity, and allowable net capacity of the individual pile are presented in Table 5.

Table 5. Bearing capacity, side friction capacity and allowable ultimate capacity of individual pile

\begin{tabular}{lr}
\hline Calculated capacity of pile for each component & Bearing capacity \\
\hline$Q_{\text {tip }}$ & $3.214,45(\mathrm{kN})$ \\
$\mathrm{Q}_{\text {side friction }}$ & $646,05(\mathrm{kN})$ \\
$\mathrm{Q}_{\text {total }}$ & $3.860,50(\mathrm{kN})$ \\
\hline Safety factor & 2 \\
\hline $\mathrm{Q}_{\text {allowable.gross }}$ & $1.930,25(\mathrm{kN})$ \\
Weight of pile & $188,50(\mathrm{kN})$ \\
$\mathrm{Q}_{\text {allowable.net }}$ & $\mathbf{1 . 7 4 1 , 7 5}(\mathrm{kN})$
\end{tabular}

\subsection{Structural Analysis of Bored Pile under Lateral Load}

Two assumptions were made for the structural analysis. Firstly, axial capacity due to buckling was not considered although it was overlong as a compression element, since the pile was surrounded by soil along its whole length. Secondly, the moment acting on pile arising from mat foundation was ignored because a possible failure of foundation-pile connection would not seriously affect the pile capacity. In case of moment connection suffer extensive damage, the connection will behave as a shear connection. In this case, only the shear force and axial force will act on the pile.

Generally, soil-pile interaction under lateral load is determined by the P-Y method [25]. In this study, soil has been modeled with horizontal linear springs along its length (Figure 9a). Nonlinear behavior of soil and mechanical property variation of soil due to depth was ignored to simplify the complexity of analysis. The soil was idealized as a series of independent linear springs. SAP2000 [26] educational version was used for the structural analysis of the pile under lateral load. Spring mechanical property (sub-grade modulus) was taken from Table 3.

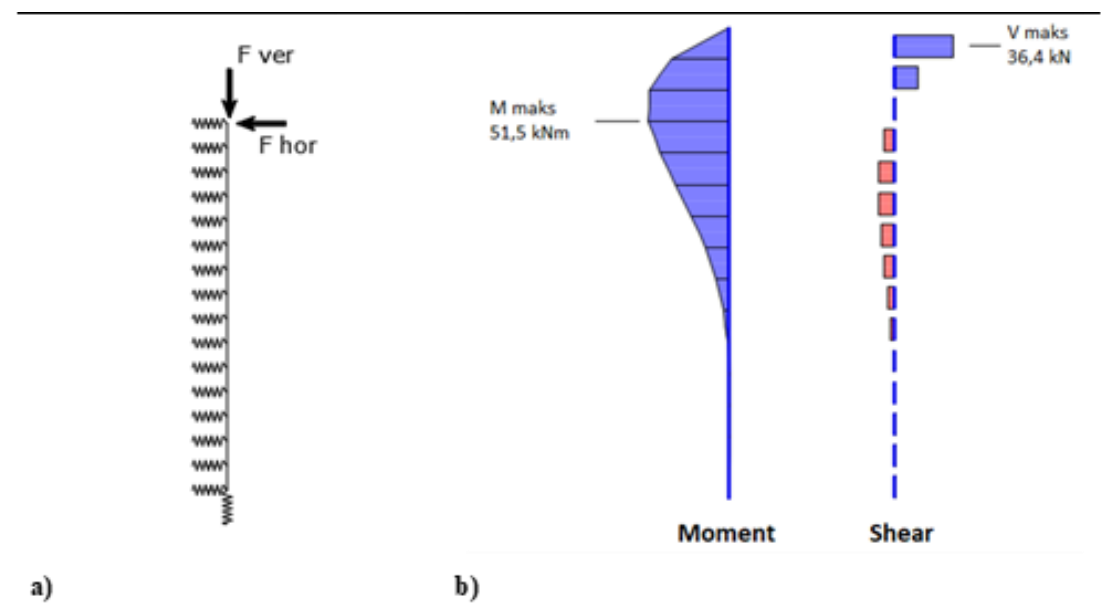

Figure 9. a) Mathematical model of the fore pile, b) Moment and shear diagram of the fore pile 


\subsection{Design of Reinforced-Concrete of Pile}

The axial load acting on the most critical pile was found as $1.738,0 \mathrm{kN}$ (174 tons) in section 3.1. As seen in Figure 9b, the moment acting on the pile due to the shear force was 51,5 $\mathrm{kNm}(5,2$ ton-meter). In the preliminary sizing, considering the axial load and soil characteristics, the diameter of the pile was chosen as 0,8 meters and the length of the pile was chosen as 15 meters. The pile interaction diagram (Figure 10) was generated to check whether the preferred pile cross-section was sufficient. The fact that the axial force-moment pair, showed with a star sign, remains inside the interaction diagram indicates that the preferred cross-section is safe.
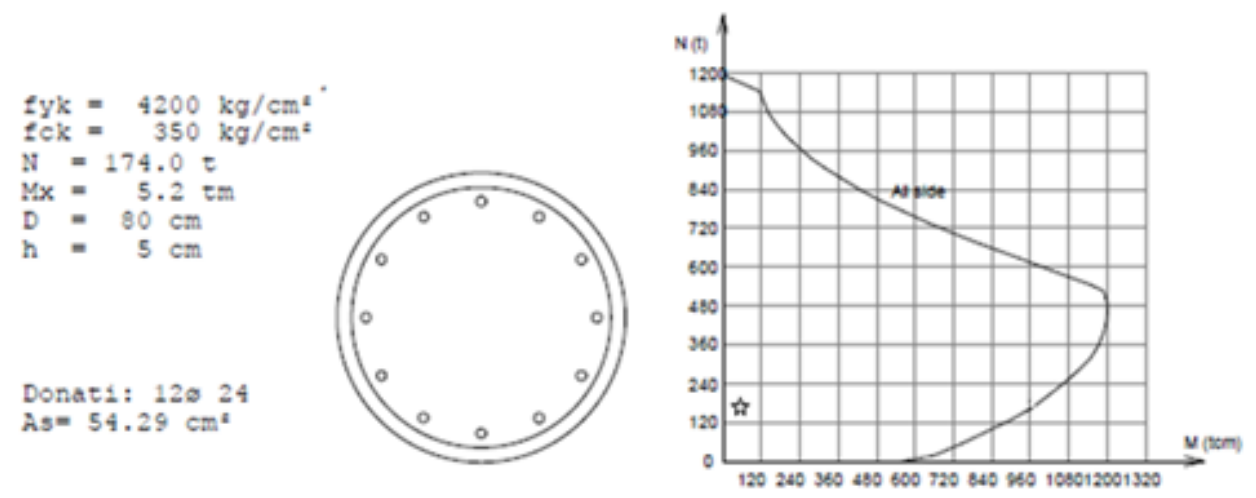

Figure 10. Axial force-Moment interaction diagram for bored-pile

\subsubsection{Longitudinal Reinforcement of Pile}

The minimum reinforcement ratio of cross-section was targeted as 0,01 , such as columns. Twelve rebar with a $24 \mathrm{~mm}$ diameter were used for reinforcement. Thus, the total reinforcement area was determined as $5.428,67 \mathrm{~mm}^{2}$ and the reinforcement percentage was determined as 0,011 . The capacity ratio of the pile was found as $0,2<1$, which shows the pile was safe.

\subsubsection{Shear reinforcement of pile}

Stirrups are placed to piles to resist shear forces. The shear design formula for a concrete element is given as below.

$$
\frac{A_{s w}}{S_{\text {required }}}=\frac{V_{w}-\left(V_{d}-0,8 * V_{c}\right)}{f_{y w d} * d}
$$

Where $A_{s w}$ is the stirrup cross-section area, $\mathrm{s}$ is the spacing between stirrups from center to center, $f_{y w d}$ is the allowable yield strength value of stirrup, $V_{d}$ is the design shear force, $V_{c}$ is the shear capacity of concrete, $d$ is the distance from center of rebar at tension zone to pile face at compression zone.

The maximum shear force for bored pile occurs at the intersection zone of mat foundation and bored pile. A smaller spacing between stirrups is required for this critical zone to obtain the ductile behavior of the pile. Figure $9 \mathrm{~b}$ shows that the maximum design shear force was determined as $36,40 \mathrm{kN}$. Double leg stirrup cross-section area $\left(\mathrm{A}_{\mathrm{sw}}\right)$ was chosen as $157 \mathrm{~mm}^{2}$. Although the shear capacity of the concrete pile was ignored, the required spacing between stirrups was found as 1.181,0 millimeters that is more than the maximum-spacing limit recommended by TEC [27]. Transverse reinforcement requirements given in TEC [27] for compression elements are shown in Table 6. 
Pile confinement zone can be considered as $15 \mathrm{~m} / 10=1,5 \mathrm{~m}$. According to Table 6 , stirrup rebar type and spacing were chosen as $(\varphi 10 / 100)$ at the confinement zone and $(\varphi 10 / 150)$ at the central zone. The minimum concrete cover $(\mathrm{cc})$ is 50 millimeters.

Table 6. Maximum spacings for spiral stirrups

\begin{tabular}{|l|l|l|l|}
\hline Maximum spacings for spiral stirrups & & \\
\hline $\mathrm{s}_{\mathrm{c}}$ & $\leq$ & $\mathrm{D} / 5$ & D: diameter of core \\
\hline (spiral spacing Confinement zone) & & $100 \mathrm{~mm}$ & \\
\hline $\mathrm{s}_{0}$ & & $\mathrm{~d}_{0} / 2$ & \\
\hline (spiral spacing Central zone) & $\leq$ & $200 \mathrm{~mm}$ & $\mathrm{~d}_{0}$ : diameter of column \\
\hline & & $12 \varphi_{\mathrm{min}}$ & \\
\hline
\end{tabular}

\section{CONCLUSION}

Wind energy turbines were built in Kahramanmaraş to benefit from wind energy within the scope of the Dilek WPP project. As a result of the geological and geotechnical studies carried out in the T-12 turbine area, it was determined that the bearing capacity of the ground was insufficient due to the weak properties of the turbines basement rock. For this purpose, it is planned to carry out the necessary improvement works with the application of a bored pile to ensure the sufficient bearing capacity of the turbine foundation.

In this study, the geotechnical and structural analysis of a bored pile under the mat foundation is presented with all details. Firstly, soil parameters were determined according to geotechnical analysis. Secondly, the structural analysis of a bored pile was performed due to the superstructure forces. Finally, the foundation size was determined as $20 \mathrm{~m}$ x $20 \mathrm{~m}$, which has an octagonal shape. Thirtyseven piles were placed under the mat foundation. The length and diameter of the bored pile were determined as 15 and 0,8 meters, respectively. The pile spacing from center to center was applied as 3 meters.

Consequently, it was determined that the bored piles to be applied to the T-2 turbine foundation provide sufficient bearing capacity. This case study is considered an important base for the basic design of wind energy turbines, which has a significant place in renewable energy sources in the world, in weak soil conditions.

\section{REFERENCES}

[1] ULU, Eylem YILMAZ; DOMBAYCI, Omer Altan. Wind Energy in Turkey: Potential and Development. The Eurasia Proceedings of Science Technology Engineering and Mathematics, 2018, 4: 132-136.

[2] http://www.kaleenerji.com.tr/projelerimiz/67-dilek-ruzgar-enerjisi-santrali.html

[3] Lorie M, Dilley PE/CPG, Laurie Hulse PEF. Foundation Design of Wind Turbines in Southwestern Alaska, a Case Study. The Arctic Energy Summit, Institute of the North Anchorage, Alaska, 1-7, 2008.

[4] Malhotra S. Selection, Design and Construction of Offshore Wind Turbine Foundations, Wind Turbines. Dr. Ibrahim Al-Bahadly (Ed.), ISBN: 978-953-307-221-0, 2011. 
[5] Buren EV, Muskulus M. Improving Pile Foundation Models for use in Bottom-Fixed Offshore Wind Turbine Applications. Energy Procedia, 2012; 24, 363-370.

[6] Catana G, Savu AA. Ealangi L. Modelling Methods For Soil-Structure Interaction Applied in Wind Turbine Foundation Design. Mathematical Modelling in Civil Engineering, 2013; 9(4), 2013-0015.

[7] Yoon GL. Kim SB. Kim HY. Reliability Analysis of Mono-Pile for Offshore Wind Foundations using The Response Surface Method. New Frontiers in Geotechnical Engineering, 2014; 26(28), 108-117.

[8] Ming-Jie Z. Ye, H. Dan-ni H. Optimization Analysis of Mono-pile Foundation for Offshore Wind Turbine Based on ANSYS Zero-order Method, Journal of Civil Engineering and Science, 2015; 4(2), 55-61.

[9] Shresth S. Design and Analysis of Foundation for Onshore Tall Wind Turbines. A Thesis Presented to the Graduate School of Clemson University, In Partial Fulfillment of the Requirements for the Degree Master of Science Civil Engineering, 23, 2015.

[10] Sandal K and Zania V. Optimization of Pile Design for Offshore Wind Turbine Jacket Foundations. 12th EAWE PhD seminar on Wind Energy in Europe, Lyngby, Denmark, 1-4, 2016.

[11] ISRM. The complete ISRM suggested methods for rock characterization, testing and monitoring, in: R. Ulusay, J.A. Hudson (Eds.), Commission on testing methods, International Society of Rock Mechanics, ISRM Turkish National Group, Ankara, 628, 2007.

[12] American Society for Testing and Materials. Standard test method of Unconfined Compressive Strength of Intact Rock Core Specimens, ASTM Stand. 04.08 (D2938) 2001.

[13] Hoek E. Brown. E.T. Underground Excavation in Rock. London, Institution of Mining and Metallurgy, 527, 1980a.

[14] Hoek E and Brown ET. Empirical Strength Criterion for Rock Masses. J. Geotech. Engng Div. ASCE 106 (GT9), 1013-1035, 1980b.

[15] Hoek E, Kaiser PK, Baeden WF. Support of Underground Excavation in Hard Rock. Roterdam, Balkema, 214, 1995.

[16] Hoek E, Marinos P, Benissi M. Applicability of the Geological Strength Index (GSI) Classification for Very Weak and Sheared Rock Masses: The Case of the Athens Schist formation. Bulletion of Engineering Geology and Environment, 1998, 57, 151-160.

[17] Marinos P. Hoek E. Estimating the Geotechnical Properties of Heterogeneous Rock Masses Such As Flysch. Bull Eng Geol Environ. 2001, 61, 85-92.

[18] Hoek E, Carranza-Torres CT, Corcum B. Hoek-Brown Failure Criterion: 2002 edition". Proceedings of the North American Rock Mechanics Society Meeting, Toronto, Canada. 1-6, 2002. 
Akgönen ve Özbek / Eskişehir Technical Univ. J. of Sci. and Tech. A-Appl. Sci. and Eng. 21 (3)- 2020

[19] Hoek E, Diederichs MS. Empirical Estimation of Rock Mass Modulus. International Journal of Rock Mechanics and Mining Sciences, 2006; 43, 203-215

[20] Rockscience inc. ROCDATA Rock mass strength analysis using the generalized Hoek-Brown failure criterion. Toronto, http://www.rockscience.com. 2017.

[21] Wyllie D.C. Foundations On Rock. Chapman-Hall. England, 333, 1992.

[22] Sowers GF. Introductory Soil Mechanics and Foundation. Macmillan, New York, 395-6, 1970.

[23] Wrana B. Pile Load Capacity-Calculation Methods. Studia Geotechnica et Mechanica, 37(4), DOI: 10.1515/sgem-2015-0048, 2015.

[24] https://theconstructor.org/geotechnical/capacity-of-pile-group-and-efficiency/9453/ 18.10. 2018.

[25] https://en.wikipedia.org/wiki/P-y_method 26.10.2018.

[26] SAP2000. Structural Analysis Program. Computers and Structures: Berkeley, CA.

[27] TEC. Turkish Earthquake Code Specification for Buildings to be Built in Seismic Zones. Ministry of Public Works and Settlement Government of Republic of Turkey. 2007. 